\title{
Sorption of dissolved organic matter by mineral soils of the Siberian forest tundra
}

\author{
MASAYUKI KAWAHIGASHI*, KLAUS KAISER†, ANDREJ RODIONOV† \\ and GEORG GUGGENBERGER† \\ *College of Bioresource Science, Nihon University, Kanagawa 252-8510, Japan, †Soil Biology and Soil Ecology, Institute of Soil \\ Science and Plant Nutrition, Martin Luther University Halle-Wittenberg, Weidenplan 14, 06108 Halle (Saale), Germany
}

\begin{abstract}
Because of low net production in arctic and subarctic surface water, dissolved organic matter (DOM) discharged from terrestrial settings plays an important role for carbon and nitrogen dynamics in arctic aquatic systems. Sorption, typically controlling the export of DOM from soil, may be influenced by the permafrost regime. To confirm the potential sorptive control on the release of DOM from permafrost soils in central northern Siberia, we examined the sorption of DOM by mineral soils of Gelisols and Inceptisols with varying depth of the active layer. Water-soluble organic matter in the $\mathrm{O}$ horizons of the Gelisols was less ( 338 and $407 \mathrm{mg} \mathrm{C} \mathrm{kg}^{-1}$ ) and comprised more dissolved organic carbon (DOC) in the hydrophobic fraction (HoDOC) $(63 \%$ and $70 \%)$ than in the $\mathrm{O}$ horizons of the Inceptisols (686 and $706 \mathrm{mg} \mathrm{C} \mathrm{kg}^{-1}, 45 \%$ and $48 \%$ HoDOC). All A and B horizons from Gelisols sorbed DOC strongly, with a preference for HoDOC. Almost all horizons of the Inceptisols showed a weaker sorption of DOC than those of the Gelisols. The C horizons of the Inceptisols, having a weak overall DOC sorption, sorbed C in the hydrophilic fraction (HiDOC) stronger than HoDOC. The reason for the poor overall sorption and also the preferential sorption of HiDOC is likely the high $\mathrm{pH}(\mathrm{pH}>7.0)$ of the $\mathrm{C}$ horizons and the smaller concentrations of iron oxides. For all soils, the sorption of HoDOC related positively to oxalate- and dithionite-citrate-extractable iron. The A horizons released large amounts of DOC with $46-80 \%$ of HiDOC. The released DOC was significantly $(r=0.78, P<0.05)$ correlated with the contents of soil organic carbon. From these results, we assume that large concentrations of DOM comprising large shares of HiDOC can pass mineral soils where the active layer is thin (i.e. in Gelisols), and enter streams. Soils with deep active layer (i.e. Inceptisols), may release little DOM because of more frequent infiltration of DOM into their thick mineral horizons despite their smaller contents of reactive, poorly crystalline minerals. The results obtained for the Inceptisols are in agreement with the situation observed for streams connecting to Yenisei at lower latitudes than $65^{\circ} 50^{\prime}$ with continuous to discontinuous permafrost. The smaller sorption of DOM by the Gelisols is in agreement with the larger DOM concentrations in more northern catchments. However, the Gelisols preferentially retained the HoDOC which dominates the DOC in streams towards north. This discrepancy can be explained by additional seepage water from the organic horizons that is discharged into streams without intensive contact with the mineral soil.
\end{abstract}

Keywords: active layer, dissolved organic matter, hydrophilic organic carbon, hydrophobic organic carbon, iron oxide, organic horizon, Permafrost, Siberia, sorption, tundra

Received 23 February 2005; revised version received 20 December 2005; accepted 30 March 2006

Correspondence: Masayuki Kawahigashi, fax + 8146684 3952, e-mail: khigashi@brs.nihon-u.ac.jp
Introduction

Sorption of dissolved organic matter (DOM) on mineral phases is an important geochemical process for carbon preservation and element cycling in soils and aquatic 
systems (Malcolm, 1985; Stevenson, 1985). Sorption is more rapid than microbial degradation (Qualls \& Haines, 1992; Kalbitz et al., 2003) and, therefore, is more efficient in removing DOM from water percolating through soil. In forest ecosystems, most dissolved organic carbon (DOC) leached from organic horizons is sorbed and retained in the subsoils (Guggenberger \& Zech, 1993; Kaiser \& Guggenberger, 2000). The sorption depends much on the contents of $\mathrm{Al}$ and Fe oxides and carbon in soils (Kaiser et al., 1996; Kahle et al., 2004). Although $\mathrm{Al}$ and $\mathrm{Fe}$ oxides act as strong sorbents (Jardine et al., 1989; Kaiser et al., 1996), indigenous soil organic matter, except for charred material, reduces the sorption of DOM to minerals by occupying sorption sites (Jardine et al., 1989; Kaiser et al., 2000). Sorption of DOM is not uniform because of its heterogeneity and polydispersity. Compounds of high molecular weight and rich in acidic functional groups and aromatic moieties sorb most strongly (McKnight et al., 1992; Gu et al., 1994).

The soil moisture and temperature regimes are significant controlling factors for the formation of pedogenic oxides in terrestrial ecosystems. In permafrost soil, the permafrost table strongly affects hydromorphy and temperature of the active layer. In the northern hemisphere, the permafrost table rises from south to north, resulting in simultaneously decreasing soil temperature and stronger hydromorphy. Reductmorphic conditions in combination with organic matter input promote release of $\mathrm{Fe}^{2+}$ from ferric oxides (Wada et al., 1975; Maie et al., 1998, 2001). Accumulation of iron oxides at the bottom of the active layer of permafrost affected soils has been attributed to the blocking the infiltration of soil water rich in $\mathrm{Fe}^{2+}$ by the permafrost table, followed by the formation of ferric oxides after re-established oxic conditions (Alekseev et al., 2003). Concurrently, hydromorphy affects net primary production as well as accumulation and/or decomposition of litter (Wang et al., 2003; Bond-Lamberty et al., 2004). Low biodegradation related to the strong hydromorphy of permafrost-affected soils may promote accumulation of litter attaining several tens of centimeter thickness (Everett \& Brown, 1982; Guggenberger et al., 2001). Composition, as well as thickness of the litter layer vary with changes in vegetation and biological activity in soils of different permafrost regime (Gholtz et al., 2000; Šantrǔčková et al., 2003). Also, DOM produced by microbial degradation of litter can be diverse depending on the permafrost regime (Neff \& Hooper, 2002). Permafrost, therefore, is likely a significant control for the production and sorption of DOM in a soil system.

As a future change in northern hemisphere, degradation of permafrost by global warming and by the increasing fire frequency may alter the formation of iron oxides, as well as may induce more oxidative condition in the active layer, in particular in the taiga regions. This alteration may promote carbon release by microbial oxidative degradation of soil organic matter and leaching of DOM due to smaller contents of sorptive iron oxides in soil. A concurrent shift to warmer soil temperature regimes toward north presumably promotes degradation of organic horizons and thus will change the production and composition of DOM. Changes in production, composition, and sorption of DOM triggered by permafrost degradation may drastically change carbon cycling in the terrestrial ecosystems of Siberia.

Here, we investigated the sorption of DOM originating from organic horizons to the underlying mineral horizons of soil profiles affected differently by permafrost. The aim was to test the hypothesis that the sorption processes in soil determine the amount and composition of DOM discharged into streams. The initial mass (IM) approach (Nodvin et al., 1986) was adopted for the sorption experiment to estimate the release of indigenous soil carbon (Kaiser et al., 1996; Kaiser \& Zech, 1997). This approach gives not an absolute measure for the sorption capacity of soils, however, nonlinearity in the relationship between added and sorbed DOC informs on increasing saturation of binding sites.

\section{Materials and methods}

\section{Soils}

Four soils, two Gelisols and two Inceptisols, representative for tundra ecosystems (Guggenberger et al., 2001) were examined: a Typic Aquorthel, a Typic Haplorthel, a Typic Cryaquept, and a Typic Eutrocryept (Fig. 1). The sampling site is a small catchment $\left(0.44 \mathrm{~km}^{2}\right)$ situated on the Karginskaya terrace on the east shore of the Yenisei, north of Igarka. The parent material is of glaciofluvial to glaciolimnic origin and represents a homogeneous coarse silty to fine sandy substrate. In the catchment, Gelisols are located on gentle slopes (inclination $<1^{\circ}$ ) and hill tops. Eutrocryepts and Cryaquepts are abundant at steeper slopes (inclination ca. $6^{\circ}$ ). All soils were covered with mor-type forest floors. Thicker organic horizons, covering Gelisols, seem to reflect the strong hydromorphy induced by a shallow active layer. Faint cloudy-shape mottles with a chroma brighter than that of the soil matrix were observed in gleyic horizons of the Typic Haplorthel, the Typic Cryaquept, and the Typic Eutrocryept (Fig. 1). These mottles indicate that redox processes strongly influence these soil horizons. 
The vegetation of the catchment comprises Larix sibirica, Picea obovata, and Pinus sibirica as dominating tree species and different types of mosses as ground vegetation. The latter cover the organic horizons at varying thickness. Samples of mineral soil horizons were taken from pits, air-dried, then homogenized by sieving $<2 \mathrm{~mm}$. The soils were analyzed with standard methods for $\mathrm{pH}\left(\mathrm{CaCl}_{2}\right)$, pedogenic iron and aluminum oxides, and total carbon and nitrogen. The specific surface area of mineral soil samples was determined by adsorption at $77 \mathrm{~K}$ and subsequent desorption of $\mathrm{N}_{2}$ with a Monosorb surface analyzer (Quantachrome Instruments, Boynton Beach, FL, USA), using freeze-dried subsamples. Also, the Oea horizons were sampled for production of DOM solutions. The organic samples were immediately transported to the laboratory and stored frozen at $-18^{\circ} \mathrm{C}$ until extraction for DOM.

\section{$D O M$}

DOM was extracted just before the sorption experiments adding deionized water $\left(10 \mathrm{~mL} \mathrm{~g}^{-1}\right.$ soil) to each Oea sample. After $15 \mathrm{~min}$ of stirring, the suspension was allowed to stand for $18 \mathrm{~h}$; thereafter, it was filtered through a $0.7 \mu \mathrm{m}$ glass fiber filter (GF/F, Whatman, Springfield Mill, UK) prerinsed with enough of deionized water to ensure removal of undesired matter. The filtrates were used as stocks for preparation of the working solutions. The concentration of total organic carbon in the filtrate was determined by wet-chemical digestion with sodium peroxodisulfate under acidic condition $(\mathrm{pH}<2)$ (LiquiTOC, Foss-Heraeus, Hanau, Germany). The distribution of DOC among operational fractions was determined by adsorption column chromatography using Amberlite XAD-8 resin (Rohm and Haas Corp., Philadelphia, PA, USA) (Aiken \& Leenheer, 1993). Organic carbon that is retained by the resin under acidic conditions $(\mathrm{pH}<2)$, represents the so-called hydrophobic fraction (HoDOC) of DOM, and is calculated as the difference between the DOC in the original solution and the DOC in the column effluent, representing the so-named hydrophilic fraction (HiDOC). Previous research suggests that the HoDOC is composed of colored, aromatic compounds whereas the HiDOC comprises primarily polysaccharide-type biomolecules and their monomers (Aiken \& Leenheer, 1993).

\section{Sorption experiment}

Sorption of DOM on the mineral soil samples of the respective profile was tested by batch sorption experiments. Initial solutions were prepared by diluting the DOM stock solutions obtained (see above) with solutions free of organic carbon but with similar $\mathrm{pH}$ (5.7 for the Aquorthel, 5.0 for the other soils) and ionic strength (electric conductivity $5 \mathrm{mS} \mathrm{m}^{-1}$ ) as the original DOM extracts. In total, six initial solutions, containing $0 \%$, $20 \%, 40 \%, 60 \%, 80 \%$, and $100 \%$ of the DOC of the stock solutions, were used. The sorption experiments were carried out by adding $40 \mathrm{~mL}$ of the initial solutions to $8 \mathrm{~g}$ of soil. After shaking for $18 \mathrm{~h}$ at $20^{\circ} \mathrm{C}$, the solution equilibrated was separated from the mineral phase by filtration through $0.45 \mu \mathrm{m}$ polyethersulfone membrane filters (Supor-450, Pall Corp., Ann Arbor, MI, USA). Carbon concentrations in solution before and after contact with soil material were determined (LiquiTOC). The distribution of DOC between the HiDOC and HoDOC after sorption was estimated by XAD-8 column chromatography. The experiments were carried out in duplicate. Sorption of DOC was evaluated by the IM approach (Nodvin et al., 1986) which relates the amount of $C$ sorbed (normalized to soil mass) to that added (normalized to soil mass). The relationship is linear as long as the sorption is not approaching the capacity of the sorbent, thus, can be analyzed by linear regression. The slope $(m)$ of the regression represents the sorption (distribution) coefficient. The intercept $(b)$ represents the amount of released carbon from the soil when a carbon-free solution is added.

\section{Statistical calculations}

Relationships between sorption coefficients and soil properties were analyzed for partial linear correlations using SPSS 10.0J for Windows.

\section{Results and discussion}

\section{Properties of DOM and soils}

With increasing thickness of the Oea horizons, less organic carbon was water soluble but the share of the HoDOC increased (Fig. 1). We assume that this reflects the difference in moisture conditions and, thus, probably microbial activity in the organic horizons. In welldrained soils having thicker active layers such as the Inceptisols, oxidative biodegradation likely results in a more rapid turnover of soil organic matter than under the strong hydromorphic conditions in Gelisols with high permafrost table. Rapid oxidative biodegradation of soil organic matter is assumed to produce DOM rich in degraded biomolecules falling into the HiDOC (Christ \& David, 1996). The smaller concentrations of water-extractable organic carbon with larger portions in the HoDOC in the thick organic horizons covering Gelisols point at a smaller microbial production of DOM. Thus, thickness of the organic horizon is probably a proxy for both the degradation conditions and 


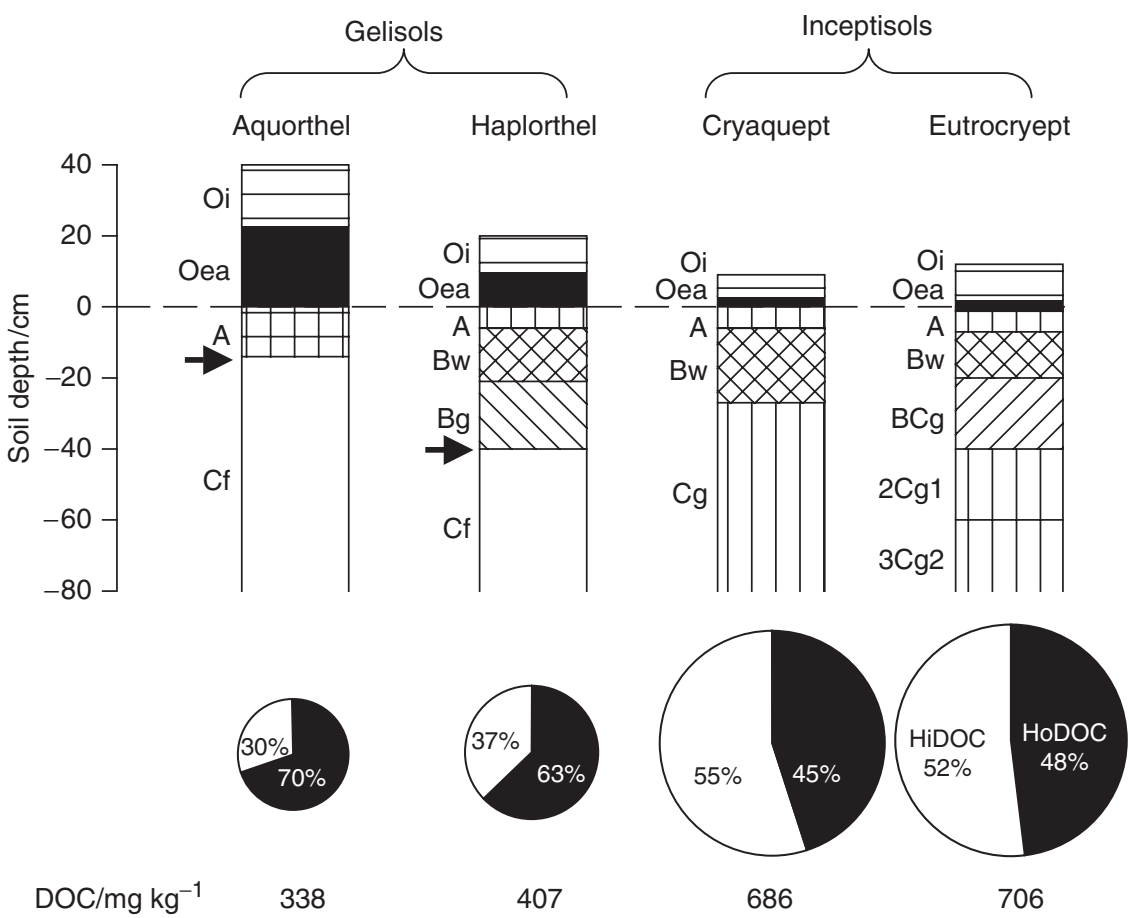

Fig. 1 Soil profiles and concentrations and distribution among fractions of dissolved organic carbon (DOC) extracted from O horizons at soil profiles. Arrows indicate permafrost tables in Gelisols.

the production of soluble organic compounds at a given site. The larger share of the HoDOC suggests that DOM from thicker organic horizons should have a stronger overall affinity for reactive mineral surfaces than DOM from thinner organic horizons. These differences in the amounts and characteristics of DOM produced in organic horizons can have major effects on the transport of organic matter in the underlying soils.

Besides the microbially mediated DOM production in the organic horizons, DOM sorption in the mineral soil horizons is the second important process controlling DOM dynamics in soils. Brief descriptions of soil profiles and physico-chemical properties of soils are presented in Table 1. The lower $\mathrm{pH}$ values in the upper mineral horizons reflect the ongoing weathering and the accumulation of organic matter. The higher values of $\mathrm{pH}$ in deeper mineral horizons hinder the weathering of primary silicates and, thus, the release of iron necessary for the formation of iron oxides. More oxalateextractable iron oxides were found in the Gelisol horizons than in the Inceptisol samples. Also, ratios of $\mathrm{Fe}_{\mathrm{ox}}$ to $\mathrm{Fe}_{\mathrm{dc}}$ in the Gelisol horizons were larger than those in the other samples, suggesting a larger release of $\mathrm{Fe}^{2+}$ under anoxic condition followed by formation of poorly crystalline ferric oxides, such as ferrihyderite, after oxic conditions have re-established (Wada et al., 1975; Maie et al., 1998, 2001). Also, in permafrost-affected soils, periodic oxic conditions in summer result in formation of ferric oxides by oxidation of dissolved $\mathrm{Fe}^{2+}$ (Alekseev et al., 2003). Largest concentrations of oxalate-extractable aluminum oxides occurred in the A horizons and gradually declined with soil depth. Thus, aluminum phases seem to relate closely to soil organic matter. The Eutrocryept and Cryaquept Cg horizons contained the smallest amounts of extractable $\mathrm{Fe}$ and $\mathrm{Al}$ of all studied horizons.

Organic carbon and nitrogen were concentrated in the surface horizons. The C-to- $\mathrm{N}$ ratios in the A horizons of Gelisols were smaller as compared with those of the other soils, probably due to a larger contribution of microbial-derived compounds such as bacterial biomass debris (Guggenberger et al., 2001). Inorganic carbon was not detected in any of the horizons.

All A horizons showed smaller specific surface areas than the underlying horizons. This is likely a result of the organic substances that cover mineral surfaces and render them inaccessible to $\mathrm{N}_{2}$. The large specific surface areas of the subsoil horizons are presumably due to oxides largely uncovered by organic matter (Kaiser \& Guggenberger, 2003).

\section{Sorption and release of DOC}

The relationships between the added and the sorbed amounts of DOC were linear for all soil samples (Fig. 2). Thus, the sorption capacity of any of the soil samples 
Table 1 Descriptions and chemical properties of soils

\begin{tabular}{|c|c|c|c|c|c|c|c|c|c|c|c|}
\hline Soil & Horizons & $\begin{array}{l}\text { Depth } \\
(\mathrm{cm})\end{array}$ & Soil color & $\begin{array}{l}\mathrm{pH} \\
\left(\mathrm{CaCl}_{2}\right)\end{array}$ & $\begin{array}{l}\mathrm{C} \\
\left(\mathrm{g} \mathrm{kg}^{-1}\right)\end{array}$ & $\begin{array}{l}\mathrm{N} \\
\left(\mathrm{g} \mathrm{kg}^{-1}\right)\end{array}$ & $\mathrm{C} / \mathrm{N}$ & $\mathrm{Fe}_{\mathrm{dc}}$ & $\begin{array}{l}\mathrm{Fe}_{\mathrm{ox}} \\
\left(\mathrm{g} \mathrm{kg}^{-1}\right)\end{array}$ & $\mathrm{Al}_{\mathrm{ox}}$ & $\begin{array}{l}\text { SSA } \\
\left(\mathrm{m}^{2} \mathrm{~g}^{-1}\right)\end{array}$ \\
\hline Typic Aquorthel & A & $0-14$ & 2.5YR 3/1.5 & 5.9 & 62.3 & 3.4 & 18.3 & 9.97 & 6.50 & 2.19 & 5.2 \\
\hline \multirow[t]{3}{*}{ Typic Haplorthel } & A & $0-6$ & 5YR 3/2 & 4.5 & 43.3 & 2.8 & 15.6 & 14.07 & 8.10 & 2.92 & 13.2 \\
\hline & $\mathrm{Bw}$ & $6-21$ & $10 Y R 3 / 4$ & 6.2 & 12.8 & 1.0 & 12.6 & 13.95 & 6.78 & 1.70 & 28.5 \\
\hline & $\mathrm{Bg}$ & $21-40$ & 10YR 4/3 & 6.9 & 10.3 & 0.9 & 11.4 & 15.26 & 7.45 & 1.49 & 30.3 \\
\hline \multirow[t]{3}{*}{ Typic Cryaquept } & A & $0-6$ & $7.5 \mathrm{YR} 4 / 3$ & 3.9 & 52.0 & 2.4 & 21.6 & 12.20 & 5.07 & 2.89 & 9.0 \\
\hline & Bw & $6-27$ & 10YR 5/4 & 5.0 & 8.2 & 0.7 & 12.4 & 11.09 & 2.21 & 1.12 & 19.3 \\
\hline & $\mathrm{Cg}$ & $27-90$ & $2.5 Y 4 / 3$ & 7.0 & 3.6 & 0.4 & 8.0 & 10.67 & 4.19 & 2.12 & 28.6 \\
\hline \multirow[t]{5}{*}{ Typic Eutrocryept } & A & $0-7$ & $7.5 \mathrm{YR} 4 / 3$ & 4.5 & 21.0 & 0.9 & 22.2 & 12.58 & 4.95 & 3.08 & 15.2 \\
\hline & Bw & $7-20$ & $7.5 \mathrm{YR} 4 / 4$ & 4.7 & 13.1 & 0.7 & 19.0 & 11.26 & 5.09 & 3.08 & 21.6 \\
\hline & $\mathrm{BCg}$ & $20-40$ & 10YR 4/4 & 6.2 & 4.5 & 0.5 & 9.7 & 10.30 & 2.44 & 1.33 & 27.4 \\
\hline & 2Cg1 & $40-60$ & 10YR 4/3 & 7.3 & 5.1 & 0.5 & 10.5 & 9.58 & 2.86 & 1.29 & 20.6 \\
\hline & 3Cg2 & 60-125 & $2.5 Y 4 / 3$ & 7.3 & 2.0 & 0.2 & 9.9 & 7.96 & 2.29 & 1.13 & 10.9 \\
\hline
\end{tabular}

dc, dithionite-citrate-extractable iron; ox, oxalate ( $\mathrm{pH}$ 3.0)-extractable iron and aluminum; SSA, specific surface area.
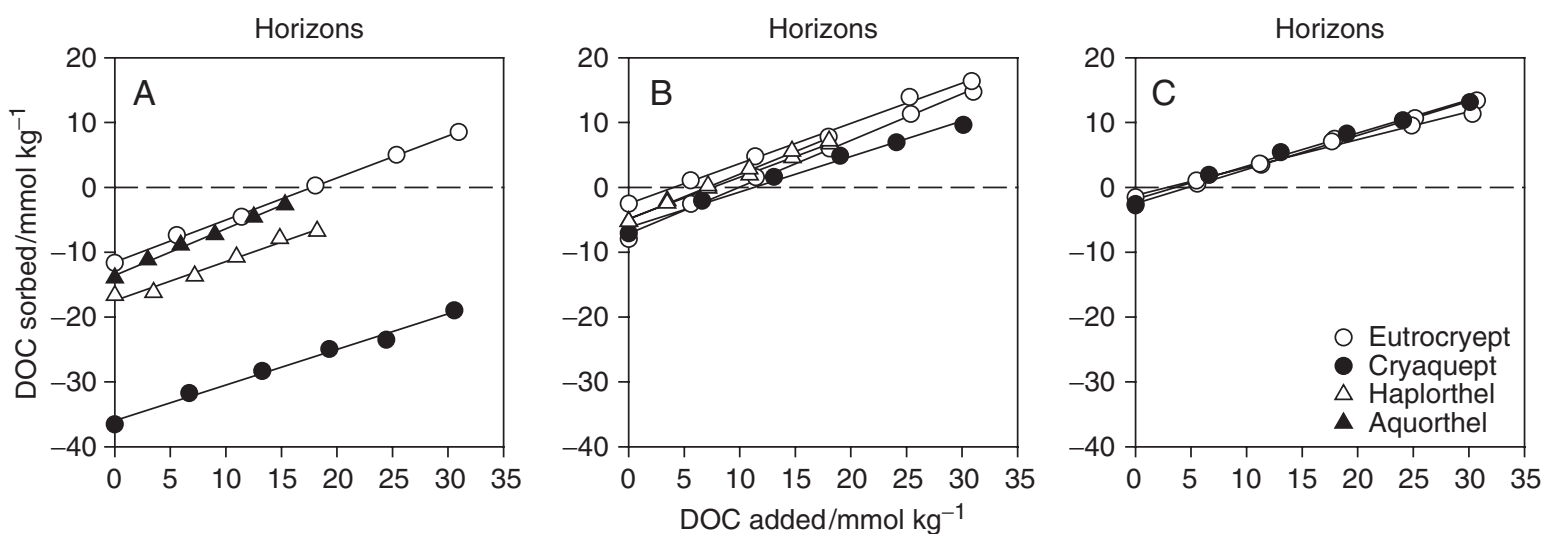

Fig. 2 Initial mass relationships for the sorption of bulk dissolved organic carbon (DOC) to the mineral horizons of an Aquorthel, a Haplorthel, a Cryaquept, and a Eutrocryept.

was not reached within the range of initial DOC concentrations used (Kaiser \& Zech, 1997). The values of the partition coefficient $m$ indicate a stronger sorption of DOC, especially of HoDOC, to all horizons of Gelisols and A horizon of Cryaquept than to almost horizons of Inceptisols (Table 2). The sorption of HoDOC seems to be controlled by the contents of iron oxides present in the soils (Fig. 3). Partial correlations with organic carbon as a controlling factor show that the partition coefficient $m$ for HoDOC relates closely to extractable iron $\left(r=0.81, P<0.01\right.$ for $\mathrm{Fe}_{\mathrm{dc}}$ and $r=0.69, P<0.05$ for $\left.\mathrm{Fe}_{\mathrm{ox}}\right)$. This indicates that the contents of iron oxides are important controls to the soils' sorption of DOC. This agrees well with previous results for northern hemisphere forest and agricultural soils (Moore et al., 1992; Kaiser et al., 1996; Kahle et al., 2004). The low retention of DOC by the $\mathrm{Cg}$ horizons may not only result from small concentrations of iron oxides therein but also from the neutral soil reaction. At $\mathrm{pH}>7$, few hydroxyl groups at the surfaces of oxides are positive charged because of close to the zero point of charge of the oxides. This hampers the binding of DOM which is negatively charged under these conditions because of the dissociation of its acidic functional groups. The soil reactions of the $\mathrm{Bw}$ and $\mathrm{Bg}$ horizons in both soils are somewhat more acidic and, therefore, in combination with the larger surface area and the larger contents of oxides, their retention of DOC is stronger than $\mathrm{Cg}$ horizons.

The sorption mechanisms of DOM onto soil samples are rather complex. Within the proposed mechanisms, the most important one is probably coordination adsorption of acidic functional groups via ligand exchange (Gu et al., 1994; Chorover \& Amistadi, 2001). 
Table 2 Parameters of the initial mass isotherms of the sorption of bulk, hydrophilic, and hydrophobic DOC to mineral soil horizons

\begin{tabular}{|c|c|c|c|c|c|c|c|c|c|}
\hline \multirow[t]{2}{*}{ Horizons } & \multicolumn{3}{|c|}{ Bulk DOC } & \multicolumn{3}{|c|}{ Hydrophilic DOC } & \multicolumn{3}{|c|}{ Hydrophobic DOC } \\
\hline & $m$ & $\begin{array}{l}b \\
\left(\mathrm{mmol} \mathrm{kg}^{-1}\right)\end{array}$ & $r^{2}$ & $m$ & $\begin{array}{l}b \\
\left(\mathrm{mmol} \mathrm{kg}^{-1}\right)\end{array}$ & $r^{2}$ & $m$ & $\begin{array}{l}b \\
\left(\mathrm{mmol} \mathrm{kg}^{-1}\right)\end{array}$ & $r^{2}$ \\
\hline \multicolumn{10}{|c|}{ Typic Aquorthel } \\
\hline A & 0.72 & 13.56 & 0.995 & 0.45 & 6.78 & 0.867 & 0.83 & 6.78 & 0.973 \\
\hline \multicolumn{10}{|c|}{ Typic Haplorthel } \\
\hline A & 0.60 & 17.50 & 0.976 & 0.18 & 11.00 & 0.393 & 0.86 & 6.43 & 0.989 \\
\hline $\mathrm{Bw}$ & 0.64 & 4.82 & 0.995 & 0.52 & 2.59 & 0.970 & 0.71 & 2.23 & 0.994 \\
\hline $\mathrm{Bg}$ & 0.70 & 4.93 & 0.996 & 0.64 & 2.95 & 0.985 & 0.73 & 1.98 & 0.998 \\
\hline \multicolumn{10}{|c|}{ Typic Cryaquept } \\
\hline $\mathrm{A}$ & 0.55 & 35.98 & 0.976 & 0.35 & 28.00 & 0.829 & 0.80 & 7.97 & 0.976 \\
\hline $\mathrm{Bw}$ & 0.55 & 6.18 & 0.988 & 0.53 & 3.36 & 0.963 & 0.57 & 2.82 & 0.997 \\
\hline $\mathrm{Cg}$ & 0.51 & 1.87 & 0.992 & 0.52 & 0.90 & 0.988 & 0.51 & 0.97 & 0.992 \\
\hline \multicolumn{10}{|c|}{ Typic Eutrocryept } \\
\hline $\mathrm{A}$ & 0.65 & 11.50 & 0.998 & 0.65 & 7.13 & 0.998 & 0.65 & 4.38 & 0.993 \\
\hline Bw & 0.72 & 7.14 & 0.996 & 0.70 & 3.62 & 0.996 & 0.74 & 3.52 & 0.996 \\
\hline $\mathrm{BCg}$ & 0.62 & 2.50 & 0.995 & 0.62 & 1.02 & 0.996 & 0.62 & 1.48 & 0.983 \\
\hline 2Cg1 & 0.53 & 2.49 & 0.997 & 0.60 & 1.29 & 0.997 & 0.45 & 1.20 & 0.992 \\
\hline $3 \mathrm{Cg} 2$ & 0.43 & 1.25 & 0.993 & 0.53 & 0.56 & 0.995 & 0.33 & 0.69 & 0.983 \\
\hline
\end{tabular}

DOC, dissolved organic carbon.
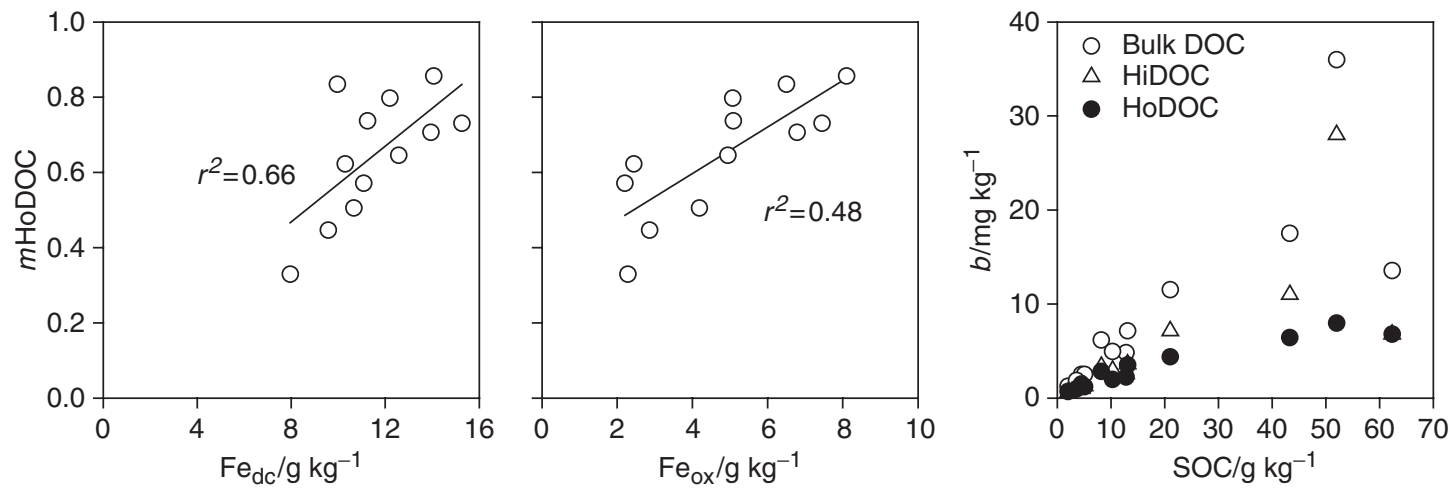

Fig. 3 Relationship between the sorption parameter $(m)$ for hydrophobic dissolved organic carbon (DOC) and iron extractable with dithionite-citrate $\left(\mathrm{Fe}_{\mathrm{dc}}\right)$ and with acidic oxalate $\left(\mathrm{Fe}_{\mathrm{ox}}\right)$; relationships of sorption parameter $(b)$ for bulk, hydrophilic and hydrophobic DOC and soil organic carbon (SOC).

Hydrophobic effects seem to enhance the sorplin (Jardine et al., 1989; Ochs et al., 1994). Organic ligands involved in ligand exchange such as carboxylic and phenolic functional groups are most abundant in the HoDOC of DOM that originates from oxidatively decomposed lignocellulose (Guggenberger et al., 1994; Dai et al., 1996). Therefore, the Gelisol horizons with larger contents of pedogenic oxides should adsorb DOM with a larger share of HoDOC preferentially. Binding of HoDOC to oxides via ligand exchange is strong and hardly reversible (Kaiser \& Guggenberger, 2000). There- fore, long-term preservation of sorbed HoDOC in the Gelisol mineral horizons can be expected. In the A horizon of the Cryaquept, ligand exchange on the iron oxide surface could also dominantly control the DOC sorption under acidic condition.

Except for the A horizon of the Cryaquept, the sorption coefficients of A and B horizons in Inceptisols were almost same for HiDOC and HoDOC. Lower affinity of HoDOC to these horizons could be attributed to the relatively smaller contents of iron oxides and the larger ratio of HiDOC to HoDOC. Further, clay minerals 
having a low zero point of charge can contribute to HiDOC retention by van der Waals forces and/or hydrophobic interactions in these horizons.

The Cg horizons from the Eutrocryept and the Cryaquept, showing relatively small sorption coefficients $m$ for bulk DOC, preferentially sorbed HiDOC. Most likely, the soil $\mathrm{pH}>7.0$ induced electrostatic repulsion of ionized carboxyl groups of DOM by deprotonated (i.e. negatively charged surface hydroxyl groups of iron oxides) and thus strongly reduced sorption of the HoDOC rich in functional groups (Schlautman \& Morgan, 1994). Under such conditions, the competition between the hydrophilic and HoDOC of DOM for binding sites at the surfaces of oxides should be minimal. Instead, the HiDOC, mainly comprising polysaccharides, may be favorably adsorbed due to van der Waals forces (Greenland, 1971; Cheshire, 1977; Sugiyama \& Kumagai, 2001). The preferential binding of HiDOC in the $\mathrm{Cg}$ horizons can be crucial for the export of DOM from Inceptisols where the DOM produced in the organic horizons is rich in compounds falling into the HiDOC. The larger specific surface area of the $\mathrm{Cg}$ horizon of the Cryaquept probably originated from the larger contents of sesquioxides as compared with the other $\mathrm{Cg}$ horizons. This presumably explains the stronger retention of HoDOC than by the $\mathrm{Cg}$ horizons of the Eutrocryepts with neutral soil reaction.

However, due to the weak bonding strength, HiDOC can be easily desorbed from mineral surfaces (Gu et al., 1994; Kaiser \& Guggenberger, 2000). Therefore, the thick $\mathrm{Cg}$ horizons may not preserve sorbed HiDOC for a long period but just retard its efflux to tributaries when concentrations of HiDOC in the soil solution are large. During periods with small concentrations of DOM in the soil solution, HiDOC retained may gradually leach from the $\mathrm{Cg}$ horizons.

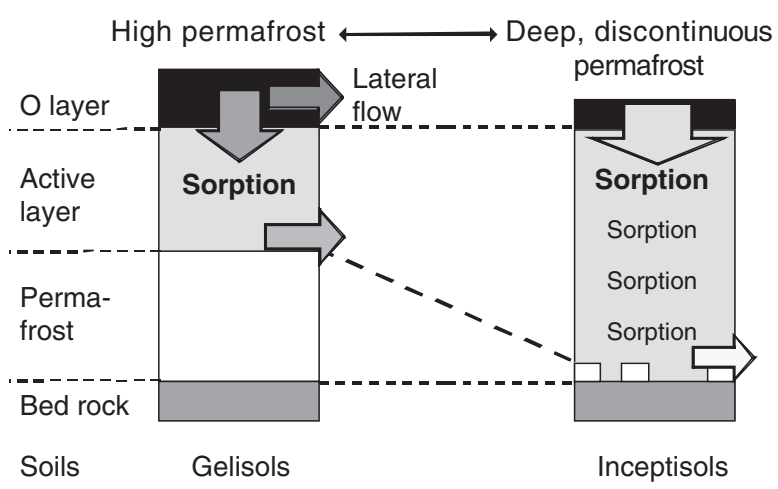

Fig. 4 Schematic illustration of flux of dissolved organic matter depending on depth of the active layer and distribution of permafrost. The different gray scales emphasize the different portions of hydrophobic fraction (HoDOC) and hydrophilic fraction in the different soil horizons with increasing proportions of HoDOC at the darker colors.
The release of indigenous organic carbon as expressed by the $b$ value of the IM isotherm was largest for the A horizons and decreased with depth (Table 2). Partial correlations between soil contents of organic carbon and $b$ values with the extractable iron $\left(\mathrm{Fe}_{\mathrm{dc}}\right)$ as controlling factor suggest a close relation $(r=0.79$, $P<0.05$ for bulk DOC, $r=0.72, P<0.05$ for HiDOC, and $r=0.98, P<0.001$ for HoDOC). The linear relationship between the $b$ values for bulk DOC and soil organic carbon (Fig. 3) suggests that the proportion of potentially soluble organic carbon was same in all tested soils. It seems that release of indigenous organic carbon depends on the quantity of organic carbon in the soils. That means, besides of the organic horizons, the mineral A horizons are also likely sources for the DOC discharged from soils, especially when the DOC concentration in the entraining solution is small. The indigenous organic carbon released from the mineral horizons was predominantly in the HiDOC (Table 2). Displacement by HoDOC from the organic horizon may enhance the release of indigenous HiDOC (McCarthy et al., 1996; Kaiser \& Zech, 1997), mainly in the upper parts of the soil profiles where the sorption of HoDOC is favored.

\section{Fate of DOM in soils with different permafrost regimes}

The fate of DOM in soils as affected by the different permafrost regime is illustrated in Fig. 4. In the Gelisols that dominate the forest tundra to northern taiga, the organic horizons likely release only small concentrations of DOM with a large portion of HoDOC into the underlying mineral soil. Part of the predominant HoDOC is then sorbed by abundant oxides in A and/or $\mathrm{Bw}$ and $\mathrm{Bg}$ horizons. Concurrently, the A horizons release large amounts of indigenous HiDOC into the percolating water. Because of the thin active layer, the overall retention of DOM should be small. Therefore, large concentrations of DOM with a large share of compounds in the HiDOC can be expected to be discharged from soil into streams. In fact, large DOC concentrations have been found in streams draining forested catchments underlain by permafrost (MacLean et al., 1999; Kawahigashi et al., 2004). However, the large portion of HoDOC (ca. 60\%) in such streams (Kawahigashi et al., 2004) contrasts the above assumptions on DOM discharge from soils. The discrepancy can be explained by additional seepage water that is discharged into streams without intensive contact with the mineral soil (i.e. either by lateral flow within the organic horizons or by rapid flow through soil along preferential flow paths; Quinton et al., 2000; Carey \& Woo, 2001; Carey, 2003; Kaiser \& Guggenberger, 2005). 
In Cryaquepts and Eutrocryepts that dominate the Siberian central taiga, DOM in seepage water from the organic horizons contains more HiDOC as compared with DOM in the northern Gelisols. Competitive sorption between HiDOC and HoDOC might occur during vertical water flow in the upper parts of the soil profiles (A and B horizons). The HoDOC, bound via ligand exchange, can likely be retained by the mineral phase for a longer time than the HiDOC, sorbed by weaker bonds. Further due to the release of indigenous organic carbon in the upper part of the profile, DOM entering the subsoils might be dominated by compounds falling into the HiDOC. The HiDOC, probably more biodegradable than the hyrdophobic one, could be microbially mineralized to $\mathrm{CO}_{2}$, evolving to the atmosphere and/or increasing the dissolved inorganic carbon (DIC) in the soil solution. Large concentrations of DIC (14-18 $\mathrm{mg} \mathrm{L}^{-1}$ ) were observed in southern tributaries draining catchments with deeper active layers (Kawahigashi et al., 2004). Striegl et al. (2005) hypothesized that the thickening the active layer increases the ratio of DIC to DOC in discharged water due to increases in biological activity and longer residence time of DOC in soil, resulting in increased decomposition. Furthermore, part of that (largely hydrophilic) DOM can be sorptively retained in the deep subsoils. Both the biodegradation and the sorptive retention limit the DOM export from soils with deeper active layers. The concentrations of DOC finally discharged into the streams should be small and predominantly in the HiDOC. This assumption is in agreement with the situation in streams at lower latitudes in central Siberia with small DOC concentrations and large proportions of $\mathrm{Hi}-$ DOC (Kawahigashi et al., 2004). The small concentrations of DOC also indicate lateral and vertical flushing of soluble organic matter from the organic horizons into the streams to be less important than for northern Siberia.

In summary, the composition of DOM produced in organic horizons changes during the vertical percolation due to preferential sorption of HoDOC in the A and $\mathrm{B}$ horizons and due to concurrent release of indigenous HiDOC, especially in A horizons. The preferential retention of HiDOC by $\mathrm{C}$ horizons, where present, may buffer the release of HiDOC. Nevertheless, in all soils the DOM discharged vertically should be dominated by HiDOC. The proportion of HiDOC, therefore, seems to be a function of the thickness of organic horizons and the depth of mineral soil horizons, and thus be a direct consequence of the permafrost regime. In northern Siberia, with soils having shallow active layers, lateral flow of DOM from the organic horizons may increase the portion of HoDOC in streams as compared with soil with deep permafrost table where much of the discharge is due to vertical percolation.

\section{Conclusion}

From the results presented above, combined with previous findings (Kawahigashi et al., 2004), a hypothetical perspective of the fate of soil-derived DOM in the central to northern Siberia can be drawn. Thickness of organic horizon, presumably being affected by permafrost regime, control the concentration and composition of DOM leached into the mineral soil. Additional DOC, mainly falling into the HiDOC, is released upon contact of the leachate with the A horizons rich in organic carbon. In turn, much of the HoDOC leached from the organic horizon is sorbed, partly by displacing indigenous HiDOC. Further retention of DOC, especially of HoDOC, in the B horizons decreases the concentrations of DOC in the percolating soil solution. The DOC leaving the $\mathrm{B}$ horizons should be dominated by HiDOC. The $\mathrm{C}$ horizons may retard some of the HiDOC and sorb little HoDOC because of the small amounts of reactive minerals and the neutral soil reaction. Because of the high permafrost table, Gelisols favor direct transport of DOM from the organic horizons to streams. Thus, the soils and their distribution in Siberia might considerably control the translocation of DOM from terrestrial into aquatic ecosystems.

Thickening active layers by permafrost degradation, either slowly by global warming or rapidly by forest fires, will change soil temperature and moisture conditions. More oxic conditions will promote degradation of organic horizons and thus will change the composition of the produced DOM to larger shares of HiDOC. Part of that DOM may be mineralized, contributing to surface water DIC. Concurrently, better drainage due to the deepening of the permafrost table might drastically retard reductive dissolution of ferric oxides and subsequently formation of fresh, poorly crystalline ones. Despite of presumably less sorptive iron oxides forming under more oxidative conditions, the increasing thickness of mineral horizons in soils with deeper permafrost table favors retardation of DOM. Stronger retention in thicker active layers can decrease discharges into aquifers and/or streams. Also, the changes in composition to larger shares of HiDOC will likely influence functions/interactions of DOM released from soil into aquatic systems.

\section{Acknowledgements}

This study was funded by the Deutsche Forschungsgemeinschaft (Gu 406/10-1). M. Kawahigashi gratefully acknowledges support by the Alexander von Humboldt Foundation. We appreciate the help of G. Polcher with the DOC measurements and of R. Mikutta with the determination of the specific surface area. 


\section{References}

Aiken GR, Leenheer JA (1993) Isolation and chemical characterization of dissolved and colloidal organic matter. Chemistry and Ecology, 8, 135-151.

Alekseev A, Alekseeva T, Ostroumov V et al. (2003) Mineral transformations in permafrost-affected soils, Northern Kolyma lowland, Russia. Soil Science Society of America Journal, 67, 596-605.

Bond-Lamberty B, Wang C, Gower ST (2004) Net primary production and net ecosystem production of a boreal black spruce wildfire chronosequence. Global Change Biology, 10, 473-487.

Carey SK (2003) Dissolved organic carbon fluxes in a discontinuous permafrost subarctic alpine catchment. Permafrost and Periglacial Processes, 14, 161-171.

Carey SK, Woo MK (2001) Slope runoff processes and flow generation in a subarctic, subalpine catchment. Journal of Hydrology, 253, 110-129.

Cheshire MV (1977) Origins and stability of soil polysaccharides. Journal of Soil Science, 28, 1-10.

Chorover J, Amistadi MK (2001) Reaction of forest floor organic matter at goethite, birnessite and smectite surfaces. Geochimica et Cosmochimica Acta, 65, 95-109.

Christ MJ, David MB (1996) Temperature and moisture effects on the production of DOC in a Spodosol. Soil Biology and Biochemistry, 28, 1191-1199.

Dai KH, David MB, Vance GF (1996) Characterization of solid and dissolved carbon in a spruce-fir Spodosol. Biogeochemistry, 35, 339-365.

Everett KR, Brown J (1982) Some recent trends in the physical and chemical characterization and mapping of Tundra soils, arctic slope of Alaska. Soil Science, 133, 264-280.

Gholtz HL, Wedin DA, Smitherman SM et al. (2000) Long-term dynamics of pine and hardwood litter in contrasting environments: toward a global model of decomposition. Global Change Biology, 6, 751-766.

Greenland DJ (1971) Changes in the nitrogen status and physical conditions of soils under pastures, with special reference to the maintenance of the fertility of Australian soils used for growing wheat. Soils and Fertilizers, 37, 897-914.

Gu B, Schmitt J, Chen Z et al. (1994) Adsorption and desorption of natural organic matter on iron oxide: mechanism and models. Environmental Science and Technology, 28, 38-46.

Guggenberger G, Bussemer S, Karpov G et al. (2001) Soils and soil organic matter along a transect from central taiga to forest tundra, Siberia. In: Sustainable Management of Soil Organic Matter (eds Rees RM, Ball BC, Campbell CD, Watson CA), pp. 330-336. CAB Publishing, Wallingford.

Guggenberger G, Zech W (1993) Dissolved organic carbon control in acid forest soils of the Fichtelgebirge (Germany) as revealed by distribution patterns and structural composition analyses. Geoderma, 59, 109-129.

Guggenberger G, Zech W, Schulten H-R (1994) Formation and mobilization pathways of dissolved organic matter: evidence from chemical structural studies of organic matter fractions in acid forest floor solutions. Organic Geochemistry, 21, 51-66.

Jardine PM, Weber NL, McCarthy JF (1989) Mechanisms of dissolved organic carbon adsorption on soil. Soil Science Society of America Journal, 53, 1378-1385.
Kahle M, Kleber M, Jahn R (2004) Retention of dissolved organic matter by phyllosilicate and soil clay fractions in relation to mineral properties. Organic Geochemistry, 35, 269-276.

Kaiser K, Guggenberger G (2000) The role of DOM sorption to mineral surfaces in the preservation of organic matter in soils. Organic Geochemistry, 31, 711-725.

Kaiser K, Guggenberger G (2003) Mineral surfaces and soil organic matter. European Journal of Soil Science, 54, 219-236.

Kaiser K, Guggenberger G (2005) Storm flow flushing in a structured soil changes the composition of dissolved organic matter leached into the subsoil. Geoderma, 127, 177-187.

Kaiser K, Guggenberger G, Zech W (1996) Sorption of DOM and DOM fractions to forest soils. Geoderma, 74, 281-304.

Kaiser K, Haumaier L, Zech W (2000) The sorption of organic matter in soils as affected by the nature of soil carbon. Soil Science, 165, 305-313.

Kaiser K, Zech W (1997) Competitive sorption of dissolved organic matter fractions to soils and related mineral phases. Soil Science Society of America Journal, 61, 64-69.

Kalbitz K, Schmerwitz J, Schwesig D et al. (2003) Biodegradation of soil-derived dissolved organic matter as related to its properties. Geoderma, 113, 273-291.

Kawahigashi M, Kaiser K, Kalbitz K et al. (2004) Dissolved organic matter in small streams along a gradient from discontinuous to continuous permafrost. Global Change Biology, 10, 1576-1586.

MacLean R, Oswood MW, Irons JG et al. (1999) The effects of permafrost on stream: a case study of two streams in the Alaskan (USA) taiga. Biogeochemistry, 47, 237-265.

Maie N, Watanabe A, Kimura M (1998) Origin and properties of humus in the subsoil of irrigated rice paddies III. Changes in binding type of humus in submerged plow layer soil. Soil Science and Plant Nutrition, 44, 331-345.

Maie N, Watanabe A, Kimura M (2001) Origin and properties of humus in the subsoil of irrigated rice paddies IV. Effect of water percolation on the binding type of humus in a submerged plow layer soil. Soil Science and Plant Nutrition, 47, 1-8.

Malcolm RL (1985) Geochemistry of stream fulvic and humic substances. In: Humic Substances in Soil, Sediment and Water: Geochemistry, Isolation and Characterization (eds Aiken GR, McKnight DM, Wershaw RL, McCarthy P), pp. 181-209. Wiley-Interscience Publication John Wiley \& Sons, New York.

McCarthy JF, Gu B, Liang L et al. (1996) Field tracer tests on the mobility of natural organic matter in a sandy aquifer. Water Resources Research, 32, 1223-1238.

McKnight DM, Bencala KE, Zellweger GW et al. (1992) Sorption of dissolved organic carbon by hydrous aluminum and iron oxides occurring at the confluence of Deer Creek with the Snake River, Summit Country, Colorado. Environmental Science and Technology, 26, 1388-1396.

Moore TR, de Souza W, Koprivnjak JF (1992) Controls on the sorption of dissolved organic carbon by soils. Soil Science, 154, 120-129.

Neff JC, Hooper GU (2002) Vegetation and climate controls on potential $\mathrm{CO}_{2}, \mathrm{DOC}$ and DON production in northern latitude soils. Global Change Biology, 8, 719-730.

Nodvin SC, Driscoll CT, Likens GE (1986) Simple partitioning of anions and dissolved organic carbon in a forest soil. Soil Science, 142, 27-35. 
Ochs M, Cosovic B, Stumm W (1994) Coodinative and hydrophobic interaction of humic substances with hydrophilic $\mathrm{Al}_{2} \mathrm{O}_{3}$ and hydrophobic mercury surfaces. Geochimica et Cosmochimica Acta, 58, 639-650.

Qualls RG, Haines BL (1992) Biodegradability of dissolved organic matter in forest throughfall, soil solution, and stream water. Soil Science Society of America Journal, 56, 578-586.

Quinton WL, Gray DM, Marsh P (2000) Subsurface drainage from hummock-covered hillslopes in the Arctic tundra. Journal of Hydrology, 237, 113-125.

Šantrưčková H, Bird MI, Kalaschnikov YN et al. (2003) Microbial characteristics of soils on a latitudinal transect in Siberia. Global Change Biology, 9, 1106-1117.

Schlautman MA, Morgan JJ (1994) Adsorption of aquatic humic substances on colloidal-size aluminum oxide particles: influence of solution chemistry. Geochimica et Cosmochimca Acta, 58, 4293-4303.

Stevenson FJ (1985) Geochemistry of soil humic substances. In: Humic Substances in Soil, Sediment and Water: Geochemistry,
Isolation and Characterization (eds Aiken GR, McKnight DM, Wershaw RL, McCarthy P), pp. 13-52. Wiley-Interscience Publication John Wiley \& Sons, New York.

Striegl RG, Aiken GR, Dornblaser MM et al. (2005) A decrease in discharge-normalized DOC export by the Yukon River during summer through autumn. Geophysical Research Letters, 32, L21413.

Sugiyama Y, Kumagai T (2001) Chemical characterization of organic carbon dissolved in natural waters using inorganic adsorbents. Analytical Science, 17, 77-82.

Wada H, Okazaki M, Takai Y (1975) Roles of water-soluble substances in dynamics of paddy soils (Part 1), dissolution of ferric hydroxide with the leachate from the water-logged soil. Japanese Journal of Soil Science and Plant Nutrition, 46, 201-209.

Wang C, Bond-Lamberty B, Gower ST (2003) Carbon distribution of a well and poorly-drained black spruce fire chronosequence. Global Change Biology, 9, 1066-1079. 